$\frac{136}{9 \cdot 84-8320}$

$\angle A--8399$

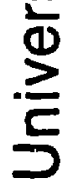




\title{
SEPARATION OF TRACE URANIUM FROM PLUTONIUM FOR SUBSEQUENT ANALYSIS
}

by

\author{
S. Fredric Marsh
}

\begin{abstract}
Trace uranium quantities are separated from plutonium metal and plutonium oxide for subsequent analysis. Samples are dissolved in hydrobromic acid or a hydrobromic acid-hydrofluoric acid mixture. The U(VI)-halide complex is separated from nonsorbed $\mathrm{Pu}(\mathrm{III})$ on an anion exchange column using sequential washes of $9 \mathrm{M} \mathrm{HBr}$, a $0.1 \mathrm{M}$ HI- $12 \mathrm{M} \mathrm{HCl}$ mixture. and $0.1 \mathrm{M} \mathrm{HCl}$.
\end{abstract}

\section{INTRODUCTION}

Uranium is an ever-present clement in plutonium materials as daughters from alpha decay of ${ }^{238} \mathrm{Pu}$. ${ }^{239} \mathrm{Pu},{ }^{240} \mathrm{Pu}$, and ${ }^{242} \mathrm{Pu}$. Uranium also can be present, mainly as ${ }^{238} \mathrm{U}$, from incompletely separated, reactor-irradiated material that produced the plutonium. In recently prepared plutonium materials that have a low abundance of the ${ }^{238} \mathrm{Pu}$ isotope, the uranium content often is below $100 \mathrm{ppm}$. Most chemical methods for determining microgram amounts of uranium are subject to interference by plutonium at a ratio of $10^{4}$ and greater. Thus, a quantitative preseparation of uranium is required that has a high separation factor for plutonium. Such a separation also provides a uranium fraction for analysis by isotope-dilution mass spectrometry, a technique used in our laboratory.

The developed procedure gives $97.5 \%$ recovery of uranium and a separation factor of $>10^{6}$ for plutonium. It involves dissolution of plutonium metal in $9 \mathrm{M} \mathrm{HBr}$ or plutonium oxide in a $0.05 \mathrm{M} \mathrm{HF}-9 \mathrm{M}$ $\mathrm{HBr}$ mixture. addition of a small quantity of bromine to ensure that uranium is hexavalent, anion exchange of the $\mathrm{U}(\mathrm{VI})$-bromide complex but not the Pu(III), final elution of plutonium with a $0 . \mathrm{IM}$ $\mathrm{HI}-12 \mathrm{M} \mathrm{HCl}$ mixture, and elution of uranium with $0.1 \mathrm{M} \mathrm{HCl}$.

\section{EXPERIMENTAL AND DISCUSSION}

\section{A. Dissolution of Samples}

When separating a trace component by ion exchange, it is advantageous to sorb it rather than the matrix components. This permits use of a small column and sr zall reagent volumes to elute the matrix components before the trace component. 
As the dissulvent, hydrobromic acid for plutonium metal or hydrobromic acid plus hydrofluoric acid for plutonium oxide converts the plutonium almost completely to Pu(III). The dissolution is rapid and complete for plutonium metal at ambient temperature and is complete within $8 \mathrm{~h}$ for plutonium oxide at sub-boiling temperature.

\section{B. Ion Exchange}

Uranium sorbs strongly, whereas plutonium. which is reduced to $\mathrm{Pu}(\mathrm{III})$ by hydrobromic acid. sorbs negligibly on anion exchange resin from hydrobromic acid concentrations above $6 \mathbf{M}^{1}{ }^{1}$ Because the elution rate of plutonium from anion exchange resin is slow in hydrobromic acid media, ${ }^{2}$ it is eluted quantitatively with a $0.1 \mathrm{M} \mathrm{HI}-12 \mathrm{M} \mathrm{HCl}$ mixture. ${ }^{3}$ Uranium then is eluted with $0.1 \mathrm{M} \mathrm{HCl}$. The selected ion exchange resin is macroporous Dow MSA-1, 50 to 100 mesh, chloride form. which was obtained from the Duw Chemical Company. This resin also is available in small quantities as AGMP-I from Bio-Rad Laboratories. The greater surface area of macroporous resin provides rapid equilibrium.

When we use the recommended procedure for $100-\mathrm{mg} \mathrm{PuO}$ samples, the recovery of $25 \mathrm{ppm}$ of uranium is $97.5 \pm 1.5 \%$, accompanied by $<0.0001 \%$ of the initial plutonium. This corresponds to a separation factor of $>10^{6}$ for plutonium. These recovery and separation factors were computed from isotope-dilution mass spectrometric analyses of uranium and plutonium added to and recovered from ion exchange columns.

\section{RECOMMENDED PROCEDURE}

\section{A. Reagents}

The acids, $9 \mathrm{M} \mathrm{HBr}, 7.4 \mathrm{M} \mathrm{HI}$, and $6 \mathrm{M} \mathrm{HCl}$, are purified of trace uranium by distillation in a quartz apparatus. The $\mathrm{HCl}$ is reconcentrated to $12 \mathrm{M}$ by bubbling $\mathrm{HCl}$ gas into it using quartz or polyethylene components with the receiver cooled in an ice bath. A nitrogen sparge during distillation of $\mathbf{H l}$ and its storage in sealed ampoules prevents air oxidation. Reagents are stored in quartz containers to minimize natural uranium contamination.

I. Dissolvent, 0.05M HF-9M HBr. Dilute $0.17 \mathrm{ml}$ of $27 \mathrm{M} \mathrm{HF}$ to $100 \mathrm{ml}$ with distilled $9 \mathrm{M} \mathrm{HBr}$.

2. Eluting solution, 0.IM HI-12M HCl. Dilute $1 \mathrm{ml}$ of $7.4 \mathrm{M} \mathrm{HI}$ to $74 \mathrm{ml}$ with the specially prepared $12 \mathrm{M} \mathrm{HCl}$. Prepare this mixture immediately before use.

3. Eluting Solution, $0.1 \mathrm{M} \mathrm{HCl}$. Dilute $1 \mathrm{ml}$ of the specially prepared $12 \mathrm{M} \mathrm{HCl}$ to $120 \mathrm{ml}$ with distilled or deionized water.

4. Bromine, Analytical Reagent grade.

\section{B. Ion Exrhange Column}

Prepare columns from disposable, 6-mm-i.d., 60-mm-long, polyethylene droppers with 2-ml reservoirs. (Suitable droppers can be obtained from the Nalge Co., Rochester, New York, article No. 6219.) Cut off the top of the dropper to form an open reservoir and insert a small wad of quartz wool in the tip. Transfer a water slurry of Dow MSA-1, 50 to 100 mesh, chloride-form resin into the column until the settled height is just below the reservoir. Immediately before use, pass $8 \mathrm{ml}$ of $0.1 \mathrm{M} \mathrm{HCl}$ and then $6 \mathrm{ml}$ of the specially prepared $12 \mathrm{M} \mathrm{HCl}$ through the column. 


\section{Sample Processing}

1. Transfer a weighed protion of plutonium metal or plutonium oxide to a Teflon beaker. (The sample size is dependent on the uranium content and the analytical method to be used. The ion exchange column handles $100-m_{E}$ plutonium portions.)

2. Dissolve the plutonium metal in $9 \mathrm{M} \mathrm{HBr}$ without heat or the plutonium oxide in $0.05 \mathrm{M} \mathrm{HF}-9 \mathrm{M} \mathrm{HBr}$ with heat. using $20 \mathrm{ml}$ of acid per gram of either type sample: cover the beaker to prevent loss.

3. Add an amount of bromine equal to $1 \mathrm{~mol} \%$ of the plutonium to oxidize the uraniun completely to U(VI).

4. Transfer a portion containing $100 \mathrm{mg}$ or less of plutonium to a freshly prepared ion exchange column having a receptacle beneath it.

5. Rinse the Teflon beaker with two $0.5-\mathrm{ml}$ volume of $9 \mathrm{M} \mathrm{HBr}$ and transfer each quantitatively to the column.

6. Pass $5 \mathrm{ml}$ of $0.1 \mathrm{M} \mathrm{HI} \cdot 12 \mathrm{M} \mathrm{HCl}$ through the column to reduce any higher oxidation states of plutonium to $\mathrm{Pu}(\mathrm{III})$.

7. Wait $10 \mathrm{~min}$ and pass another $10 \mathrm{ml}$ of $0.1 \mathrm{M} \mathrm{HI}-12 \mathrm{M} \mathrm{HCl}$ through the column to complete the reduction and elution of plutonium.

8. Piace a new receptacle free of uranium contamination under the column for collection of the uranium fraction.

9. Pass $5 \mathrm{ml}$ of $0.1 \mathrm{M} \mathrm{HCl}$ through the column to elute the uranium.

\section{REFERENCES}

I. S. F. Marsh. J. E. Alarid. C. F. Hammond. M. J. McLeod. F. R. Roensch. and J. E. Rein. "Anion Exchange of 58 Elements in Hydrobromic Acid and in Hydriodic Acid." Los Alamos Scientific Laboratory report LA-7084 (February 1978).

2. R. P. Larsen and R. D. Oldham. "Anion Exchange Separation of Plutonium in Hydrochloric-Hydrobromic Acid Media," Talanta 22(7). 577-580 (1975).

3. S. F. Marsh. M. R. Ortiz. R. M. Abernathey, and J. E. Rein. "Improved Two-Column Ion Exchange Separation of Plutonium. Uranium. and Neodymium in Mixed Uranium-Plutonium Fuels for Burnup Measurement." Los Alamos Scientific Laboratory report LA-5568 (June 1974). 